\title{
Commentary on Chavez-Ayala et al.'s “Violencia y la Salud Mental Asociados a Pensar o Haber Intentado Emigrar Internacionalmente por Adolescentes Mexicanos"
}

\author{
Comentario acerca del artículo "Violencia y la \\ Salud Mental Asociados a Pensar o Haber \\ Intentado Emigrar Internacionalmente por \\ Adolescentes Mexicanos" de Chavez-Ayala et al.
}

\author{
Comentário sobre o artigo "Violencia y la Salud \\ Mental Asociados a Pensar o Haber Intentado \\ Emigrar Internacionalmente por Adolescentes \\ Mexicanos" de Chavez-Ayala et al.
}

Lorena M. Estrada-Martínez 1

doi: 10.1590/0102-311X00089317
A significant number of studies examining the impact of immigration on health have found that time spent in the United States is associated with risk for negative mental health and behavioral outcomes 1 . This association has been found among adolescents and adults, with individual- (i.e., time since arrival) and family-based (across generations) measures, and among immigrants from various parts of the world. Many researchers have attributed these findings to an erosion of social ties and cultural values, and higher levels of exposure to stress, violence, and discrimination in the United States vis-à-vis countries of origin. Although US-based scholars have debated the pathways of such association for decades, more often than not they fail to incorporate key evidence that emerges from sending nations 2 . We do so at our own peril. Understanding behavioral and mental health outcomes of immigrants, or how they change over time, requires us first to understand the multiple factors that push someone into migrating in the first place. (A significant number of studies in other countries have found similar associations. Given the focus on the original article, I focus on the research literature based on the United States). Social scientists have relied on models that emphasize the economic and labor drivers of international migration. Several scholars have also noted the role of war, terrorism, and violence in population displacement 3 . Much less is known about how exposure to other forms of family or community violence - most of which are alarmingly common in the United States - influences decisions to migrate or health outcomes once in the United States.

The development of effective social policies and interventions to address issues of violence and mental health requires such information. The study presented by Chavez-Ayala et al. begins to assess a complex dynamic with important implications for public health and immigration policies, both in Mexico and the United States. As a researcher of youth violence and mental health among Latinos in the United States, I find these types of analyses to be especially salient to understanding the convergence of interpersonal, family, and community dynamics with structural drivers of migration. Chavez-Ayala and colleagues' findings of significant direct and indirect associations between exposure to violence and poor mental health are consistent with findings from research in the United States and elsewhere. The authors take the study of these relationships one step further by examining how violence exposure and mental health influence intention to migrate. However, there are several factors that need additional consideration, which I note below.
${ }^{1}$ College of Public and Community Services, University of Massachusetts Boston, Boston, U.S.A.

\section{Correspondence}

L. M. Estrada-Martínez

College of Public and

Community Services,

University of Massachusetts Boston.

100 William T. Morrissey

Blvd, Boston / Massachusetts

- 02125, U.S.A.

lorena.estrada@umb.edu 


\section{Refining the outcome}

One of the things I teach my research methods students is to beware of double-barreled questions, as it makes it harder to know exactly which element of the question participants are responding to. This is a significant problem that future data collection efforts need to address. Researchers and practitioners involved with the questionnaire design of the Encuesta Nacional sobre Exclusion, Intolerancia $y$ Violencia en las Escuelas de Educación Media Superior (Segunda Encuesta Nacional), should consider that there may be differences in what makes someone (a) think about the possibility of migrating, (b) make plans of migrating, and (c) actually migrate.

The outcome's inclusion of both thinking about and attempting to migrate obscures pathways by which people make decisions. It also risks overlooking important sources of variability in the types of experiences and resources of those who only consider moving and those who actually move. This has implications for the validity of some of the authors' interpretations. There are multiple steps between considering migration and actually attempting migration. Some of these have to do with financial resources and social capital at home and in a specific location in the United States (e.g., do they know anyone in the area? What is their relationship to those persons?). The use of a single item as an outcome (although presumably the authors were not the decision makers of its wording), is a key limitation and groups together two distinct processes.

\section{Geography and proximity}

The pathways of exposure to violence and intention to move may also be indirectly influenced by the city and state in which the adolescent lives. Whenever possible it is important to consider (a) indicators of socioeconomic status, (b) indicators of violence (e.g., crime rates, domestic violence), and (c) the distance to the United States. Although these factors are indicative of larger social issues, they provide an important backdrop to interpreting findings in different contexts. As with other large countries, Mexico's different regions and states have distinct social and economic issues that influence decisions and opportunities to migrate. For example, it is possible that people living in Northern states closer to the US-Mexico border have a different set of reasons and resources to migrate than those who live in Mexico City or in Southern states.

\section{Statistical approach}

Another important consideration is the statistical approach employed by the authors. While basic mediating models are an important first step to determine relationships between concepts, a more accurate picture of the pathways that link exposure to multiple types and contexts (i.e., school, communities, home) of violence, mental health, and migration requires a different methodological approach. As it stands, I would caution not to overstate possible interpretations of results. For example, the Chavez-Ayala et al. suggest that adolescents exposed to violence at school or at home and who belong to higher social classes are more likely to consider and/or attempt to migrate because they have developed a mental health problem. This claim may be premature. Although it is quite possible that this is one of the dynamics at hand, we must consider whether it is also likely for adolescents of higher socioeconomic status to have additional resources that allow them to view migrating as a truly viable option. Even in the case of high levels of exposure to violence, socioeconomic status would be a primary driver of migration mostly among those people who do have the resources to do so. A closer examination that distinguishes intention to migrate vis-à-vis actually migrating would provide important insight as to the primary causes of these decisions. Given the study design and sample size of the Segunda Encuesta Nacional, future studies could use path analyses and structural equation modeling (SEM) as a way to gauge the complex relation between variables. Importantly, this approach allows researchers to simultaneously examine intent and attempt to migrate to the United States as an agent, mediator, or outcome variable. 
The surprising outcome of the 2016 US presidential elections signals that the United States in going through turbulent social and political shifts that have resulted in increased hostility against Mexican immigrants and strong pro-nativist attitudes. Given this landscape, we should welcome and support the rigorous work that Mexican scholars are engaged in. Even further, we should stress the need for cross-national collaborations and support for panel studies that allow us to examine the links between exposure to violence and mental health on both sides of the border. I, for one, look forward to such collaborations.

1. Alegria M, Canino G, Shrout PE, Woo M, Duan N, Vila D, et al. Prevalence of mental illness in immigrant and non-immigrant U.S. Latino groups. Am J Psychiatry 2008; 165:359-69.

2. Acevedo-Garcia D, Sanchez-Vaznaugh EV, ViruellFuentes EA, Almeida J. Integrating social epidemiology into immigrant health research: a crossnational framework. Soc Sci Med 2012; 75:2060-8.
3. De Jong J. Trauma, war, and violence: public mental health in socio-cultural context. New York: Kluwer Academic Publishers; 2002. 